\title{
PENGEMBANGAN BUKU AJAR MODULAR UNTUK PENDIDIKAN ANAK BERBAKAT
}

\author{
Benny A. Pribadi (bennyp@ut.ac.id) \\ Asnah Said \\ Surachman Dimyati \\ Unviersitas Terbuka
}

\begin{abstract}
The aim of this research is to develop a modular instructional material that can be used as a model to support educational program for gifted students. Research and development approach, proposes by Borg, Gall and Gall (2007), was used to develop the material. Borg, Gall and Gall advises to apply ten steps of Dick, Carey and Carey (2010) model for developing an instructional materials. Those ten steps includes: (1) identify isntructional goals; (2) conduct instructional analysis: (3) identify entry behaviors; (4) write performace objectives; (5) develop criterion referenced tests; (6)develop instructional strategy; (7) develop and select instructional materials; (8) develop and conduct formatif evaluation; (9) revise instruction; (10) develop and conduct summative evaluation. The ten steps was used to develop modular approach of instructional materials that can be used to increase the knowledge and skills of teachers and educators in designing learning program for gifted children.
\end{abstract}

Keywords: design and development, instructional materials, modular approach

\begin{abstract}
ABSTRAK
Tujuan dari penelitian ini adalah untuk mengembangkan materi pembelajaran modular yang dapat digunakan sebagai model untuk mendukung program pendidikan untuk siswa berbakat. Penelitian dan pendekatan pembangunan, dikeemukakan oleh Borg, Gall dan Gall (2007), digunakan untuk mengembangkan materi. Borg, Gall dan Gall menyarankan untuk menerapkan sepuluh langkah dari Dick, Carey dan Carey (2010) model untuk mengembangkan bahan ajar. Sepuluh langkah tersebut meliputi: (1) mengidentifikasi tujuan instruksional; (2) melakukan analisis instruksional: (3) mengidentifikasi perilaku entri; (4) menulis tujuan performace; (5) mengembangkan kriteria referensi tes; (6) mengembangkan strategi pembelajaran; (7) mengembangkan dan memilih bahan pembelajaran; (8) mengembangkan dan melakukan evaluasi formatif; (9) merevisi instruksi; (10) mengembangkan dan melakukan evaluasi sumatif. Kesepuluh langkah ini digunakan untuk mengembangkan pendekatan modular bahan ajar yang dapat digunakan untuk meningkatkan pengetahuan dan keterampilan para guru dan pendidik dalam merancang program pembelajaran untuk anak-anak berbakat.
\end{abstract}

Kata kunci: bahan ajar, desain dan pengembangan, pendekatan modular 
Anak berbakat atau gifted children merupakan anugrah bagi suatu negara. Namun demikian, hal ini memerlukan adanya penanganan yang konfrehensif. Undang-undang tentang anak berbakat menyatakan bahwa: "...Warga negara yang memiliki potensi kecerdasan dan bakat istimewa berhak memperoleh pendidikan khusus" (Pasal 5, ayat 4). Selain itu, dikemukakan pula bahwa "...Setiap peserta didik pada setiap satuan pendidikan berhak mendapatkan pelayanan pendidikan sesuai dengan bakat, minat dan kemampuannya" (pasal 12, ayat 1b). Kenyataaan ini merupakan berita yang menggembirakan bagi warga negara yang memiliki bakat khusus dan tingkat kecerdasan yang istimewa untuk mendapatkan pelayanan pendidikan yang sebaik-baiknya.

Walaupun Undang-undang tentang anak berbakat sudah tersedia, namun penyelenggaraan program pendidikan anak berbakat saat ini menunjukkan penanganan dan sistem yang belum dilakukan secara terpadu. Setiap institusi menyelenggarakan programnya dengan pendekatan khas masing-masing. Hal ini disebabkan kurangnya pengetahuan yang dimiliki oleh guru dan pendidik tentang cara menangani pendidikan anak berbakat secara efektif dan efisien.

Satria Dharma (2008) dalam wordpress.com mengemukakan bahwa "...Berdasarkan statistik, $20 \%$ siswa gagal yang diuji dalam sebuah tes ternyata masuk dalam kategori gifted alias anak-anak cerdas". Tes ini dilakukan oleh Davidson Institute for Talent Development yang peduli pada nasib anak-anak cerdas berbakat yang tidak mendapatkan perhatian dan pelayanan yang sesuai dengan kebutuhan mereka. Anak-anak cerdas tersebut dinilai buruk oleh sekolah mereka justru karena mereka tidak lagi merasa tertantang dan merasa frustrasi dengan kurikulum rata-rata yang diberikan kepada mereka. Bakat dan kecerdasan yang tidak tertangani dengan baik akan hilang percuma dan ini merupakan kerugian bagi sebuah negara.

Bahan rujukan atau referensi yang memuat informasi dan pengetahuan yang terkait dengan pendidikan anak berbakat saat ini masih sangat terbatas. Referensi yang berlimpah pada umumnya ditulis dalam bahasa asing yang kajiannya belum tentu sesuai dengan konteks dan kultur masyarakat di Indonesia.

Artikel ini mengelaborasi tentang pengembangan buku ajar modular khususnya untuk aktivitas pembelajaran anak berbakat sehingga dapat digunakan secara efektif dan efisien untuk keperluan penyelenggaraan program pendidikan anak berbakat di Indonesia. Buku ajar modular yang dikembangkan dalam penelitian ini diharapkan dapat menjadi salah satu bahan rujukan yang dapat dipelajari untuk memperoleh pengetahuan dan informasi yang diperlukan dalam mendesain aktivitas pembelajaran untuk anak berbakat.

Penelitian ini bertujuan untuk menambah referensi dan bahan pembelajaran - learning material - baru yang berkaitan dengan penanganan dan pendidikan anak berbakat di Indonesia. Buku belajar yang dihasilkan dari kegiatan penelitian pengembangan ini adalah buku ajar modular yang dapat digunakan sebagai bahan untuk melakukan aktivitas belajar mandiri. Dengan kata lain, penelitian ini akan menghasilkan buku ajar modular yang dapat digunakan untuk menunjang aktivitas belajar mandiri baik secara formal maupun secara informal oleh penggunanya.

Buku ajar modular yang dikembangkan dalam penelitian ini difokuskan pada pembahasan materi tentang bagaimana mendesain pembelajaran untuk anak berbakat. Setelah mempelajari buku ajar modular ini pengguna diharapkan dapat mengaplikasikan prinsip-prinsip desain sistem pembelajaran yang diperlukan untuk mengembangkan dan menciptakan aktivitas pembelajaran anak berbakat yang efektif dan efisien. 


\section{MODEL PENELITIAN DAN PENGEMBANGAN}

Penelitian ini menggunakan pendekatan atau model penelitian dan pengembangan atau research and development. Model penelitian pengembangan Borg, Gall dan Gall (2009) dipilih untuk digunakan dalam penelitian Pengembangan Buku Ajar Modular Pendidikan Anak Berbakat ini. Model penelitian dan pengembangangan yang dikemukakan oleh Borg, Gall dan Gall merujuk kepada langkah-langkah Model Desain Sistem Pembelajaran yang dikemukakan oleh Dick, Carey dan Carey (2007).

Model desain yang dikemukakan oleh Dick, Carey dan Carey terdiri dari sepuluh langkah desain dan pengembangan yaitu: (1) Mengidentifikasi tujuan pembelajaran; (2) Melakukan analisis instruksional; (3) Menganalisis karakteristk siswa dan konteks pembelajaran; (4) Merumuskan tujuan pembelajaran khusus; (5) Mengembangkan instrumen penilaian; (6) Mengembangkan strategi pembelajaran; (7) Mengembangkan dan memilih bahan ajar; (8) Merancang dan mengembangkan evaluasi formatif; (9) Melakukan revisi terhadap program pembelajaran; (10) Merancang dan mengembangkan evaluasi sumatif.

Diagram berikut menggambarkan langkah-langkah dalam model Desain Sistem Pembelajaran yang dikemukakan oleh Dick, Carey dan Carey (2007).

\section{Dick and Carey Design Model}

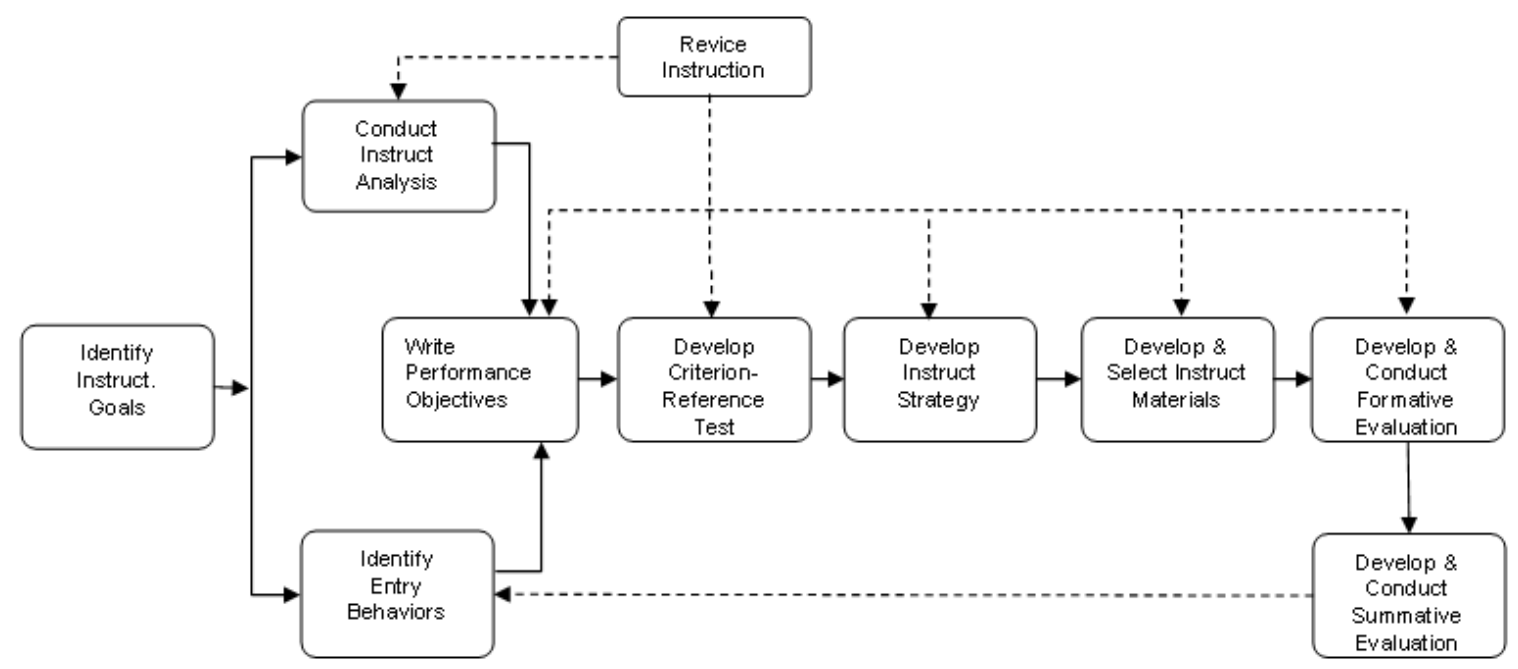

Gambar 1. Model desain sistem pembelajaran Dick, Carey dan Carey

Langkah pertama yang dilakukan dalam penelitian ini adalah menentukan kemampuan atau kompetensi yang perlu dimiliki oleh siswa setelah menempuh program pembelajaran. Kompetensi pengguna menjadi dasar dalam mengembangkan buku ajar modular untuk anak berbakat.

Setelah melakukan identifikasi tujuan pembelajaran, langkah selanjutnya yang dilakukan adalah melaksanakan analisis instruksional yaitu sebuah prosedur yang digunakan untuk menentukan keterampilan-keterampilan dan pengetahuan yang relevan dan diperlukan oleh pengguna buku ajar untuk mencapai kompetensi atau tujuan pembelajaran. 
Hal lain yang dilakukan dalam menerapkan model desain sistem pembelajaran dalam penelitian ini adalah melakukan analisis terhadap karakteristik siswa yang akan belajar dan juga konteks pembelajaran. Kedua langkah tersebut - analisis instruksional dan analisis siswa - dilakukan secara paralel. Berdasarkan hasil analisis instruksional, peneliti mengembangkan kompetensi atau tujuan pembelajaran spesifik (instructional objectives) yang perlu dikuasai oleh siswa untuk mencapai tujuan pembelajaran atau kompetensi umum umum (instructional goal).

Berdasarkan tujuan atau kompetensi khusus yang telah dirumuskan, langkah selanjutnya adalah mengembangkan alat atau instrumen penilaian yang mampu mengukur pencapaian hasil belajar siswa. Hal ini dikenal juga dengan istilah penilaian hasil belajar. Dalam menentukan instrumen penilaian, hal penting yang perlu diperhatikan adalah instrumen penilaian yang dipilih harus dapat digunakan untuk mengukur performa siswa dalam mencapai tujuan pembelajaran yang telah dirumuskan.

Setelah menentukan instrumen penilaian hasil belajar, peneliti dan pengembang program menentukan strategi yang dapat digunakan agar buku ajar modular yang dikembangkan dapat memfasilitasi pengguna untuk mencapai kompetensi yang telah ditentukan. Hal ini dikenal sebagai langkah penentuan strategi pembelajaran.

Pada tahap selanjutnya peneliti menerapkan strategi pembelajaran yang telah dirancang dalam tahap sebelumnya ke dalam buku ajar modular yang dikembangkan. Istilah buku ajar pada dasarnya sama dengan media pembelajaran yaitu sesuatu yang dapat digunakan dalam membawa informasi dan pesan dari sumber belajar kepada siswa (Heinich dan kawan-kawan, 2005)

Evaluasi formatif adalah langkah selanjutnya yang dilakukan untuk mengumpulkan data yang terkait dengan kekuatan dan kelemahan buku ajar modular yang dikembangkan. Hasil dari proses evaluasi formatif digunakan sebagai bahan masukan atau input untuk memperbaiki draf buku ajar modular. Implementasi evaluasi formatif dalam penelitian ini dilakukan dengan menerapkan tiga tahap evaluasi yaitu: evaluasi satu-satu, evaluasi kelompok kecil dan evaluasi lapangan. Pada tahap ini dilibatkan ahli desain pembelajaran, ahli materi dan ahli media. Selain itu, penelitian ini juga melibatkan sejumlah siswa sebagai responden.

Langkah akhir dari proses penelitian adalah melakukan revisi terhadap draf buku ajar modular untuk anak berbakat. Data yang diperoleh dari prosedur evaluasi formatif dirangkum dan ditafsirkan untuk mengetahui kelemahan-kelemahan yang dimiliki oleh buku ajar modular. Pada penelitian dan pengembangan buku ajar modular untuk anak berbakat tahap evaluasi sumatif, seperti yang tercantum dalam model desain sistem pembelajaran yang dikemukakan oleh Dick, Carey dan Carey, tidak dilakukan oleh peneliti.

\section{KONSEP DAN KARAKTERISTIK ANAK BERBAKAT}

Kecerdasan seseorang kerap dikaitkan dengan tingkat IQ atau Intelligent Quotient yang dimiliki. Bainbridge (2013) mengemukakan definisi IQ sebagai pengukuran kecerdasan relatif yang ditentukan oleh tes yang standar. Mayoritas individu memiliki IQ antara 85 sampai dengan 115. Kecerdasan juga kerap dikaitkan dengan bakat yang dimiliki oleh individu.

Pada tahun1969 Francis Golta pertama kali menggunakan istilah anak berbakat atau gifted children. Istilah anak berbakat merujuk kepada anak-anak yang memiliki potensi tingkat kecerdasan tinggi. Terman dan Hollingworth, ilmuwan Eropa, menyatakan bahwa kecerdasan yang dimiliki oleh seseorang pada dasarnya diturunkan dari orang tuanya (genetik).

Joseph Renzulli (1978) dalam http://namiho.wordpress.com/2011/04/01/anak-berbakat/, mengemukakan makna anak berbakat sebagai satu interaksi di antara tiga sifat dasar manusia yang 
menyatu yang terdiri dari kemampuan umum dengan tingkatnya di atas kemampuan rata-rata, komitmen yang tinggi terhadap tugas-tugas dan juga kreativitas yang tinggi. Kementerian Pendidikan dan Kebudayaan pada tahun 2003 menetapkan standar anak berbakat yaitu anak-anak yang memiliki IQ 140 ke atas. Kecerdasan menurut Woolfolk (2004) adalah kemampuan-kemampuan dalam memperoleh dan menggunakan pengetahuan untuk memecahkan masalah dan beradaptasi dengan dunia sekitar.

Departemen pendidikan Amerika Serikat mendefinisikan konsep anak berbakat sebagai berikut.

Children and youth with outstanding talent perform or show the potential or performing at remarkably high levels of accomplishment when compared with others of their age, experience, or environment. These children and youth exhibit high capability in intelectual, creative, and/or artistic areas, poses unusual leadership capacity, or excel in specific academic fields. They require services or activities not ordinarily provided by the schools. Outstanding talents are present in children and youth from all cultural groups, across all economic strata, and in all areas, across all economic strata, and in all areas of human endeavor. (p. 140).

Sebelum mendesain dan mengembangkan buku ajar modular untuk anak berbakat hal penting yang terlebih dahulu perlu dilakukan adalah mengenal dengan cermat anak berbakat dan karakteristik perilakunya. Bainbridge (2013) mengelompokkan anak berbakat berdasarkan tingkat IQ yang dimiliki dalam tabel sebagai berikut:

Tabel 1.Pengelompokan Anak Berbakat Berdasarkan Tingkat IQ.

\begin{tabular}{cc}
\hline KELOMPOK ANAK BERBAKAT & TINGKAT IQ \\
\hline Mildly gifted & $115-120$ \\
Moderately gifted & $130-134$ \\
Highly gifted & $145-159$ \\
Exceptionally gifted & $160-179$ \\
Profoundly gifted & 180 \\
\hline
\end{tabular}

Bainbridge juga mengemukakan beberapa karakteristik anak berbakat yaitu: (1) very observant; (2) extremely curious; (3) intense interests; (4) excellent memory; (4) long attention span; (5) excellent reasoning skills; (6) well-developed powers of abstraction, conceptualization, and synthesis; (7) quickly and easily sees relationships in ideas, objects, or facts; (8) fluent and flexible thinking; (9) elaborate and original thinking; (10) excellent problem solving skills; (11) learns quickly and with less practice and repetition; (12) unusual and/or vivid imagination.

Menurut Martinson (1974) anak berbakat memiliki ciri-ciri sebagai berikut: (1) Gemar membaca pada usia lebih muda; (2) Membaca lebih cepat dan memiliki perbendaharaan kata yang luas serta mempunyai rasa ingin tahu yang kuat; (3) Mempunyai minat yang luas terhadap suatu masalah, mempunyai inisiatif, dan mampu bekerja sendiri serta menunjukkan keaslian (orisinalitas) dalam ungkapan verbal; (4) Memberi jawaban-jawaban yang baik; (5) Memiliki banyak gagasan; (6) Luwes dalam berpikir; (7) Terbuka terhadap rangsangan-rangsangan dari lingkungan. (8) Mempunyai pengamatan yang tajam; (9) Dapat berkonsentrasi untuk jangka waktu panjang, terutama terhadap tugas atau bidang yang diminati; (9) Berpikir kritis, juga terhadap diri sendiri; (10) Senang mencoba hal-hal yang bersifat baru; (10) Mempunyai daya dan kemampuan abstraksi, konseptualisasi, dan sintesis yang tinggi; (11) Senang terhadap kegiatan intelektual dan pemecahan masalah; (12) Cepat 
menangkap hubungan-hubungan sebab akibat; (13) Berperilaku terarah kepada tujuan; (14) Mempunyai daya imajinasi yang kuat; (15) Mempunyai banyak kegemaran atau hobi; (16) Mempunyai daya ingat yang kuat dan tidak cepat puas dengan prestasi yang dicapai: (17) Peka atau sensitif dan kerap menggunakan firasat (intuisi); (18) Menginginkan kebebasan dalam gerakan dan tindakan.

\section{STRATEGI PEMBELAJARAN UNTUK ANAK BERBAKAT}

Buku ajar modular yang dikembangkan dalam penelitian ini diharapkan dapat digunakan sebagai bahan rujukan oleh guru dan pendidik dalam mendesain program pembelajaran yang efektif bagi anak berbakat. Salah satu kompetensi yang perlu dikuasai oleh guru dan pendidik setelah mempelajari buku ajar modular ini adalah kemampuan dalam mendesain program pembelajaran yang efektif dan efisien untuk anak berbakat. Oleh karena itu, desain bahan ajar tersebut perlu mempertimbangkan, merefleksikan karakteristik anak berbakat. Menurut Van Tassel-baska (2013), faktor-faktor yang perlu dipertimbangkan dalam mendesain program pembelajaran untuk anak berbakat adalah sebagai berikut.

a. Content, process, and product standards that exceed the state-adopted standards for all students;

b. Goals and indicators that require students to demonstrate depth and complexity of knowledge and skills;

c. Instructional strategies that accommodate the unique needs of gifted and talented learners;

d. A confluent approach that incorporates acceleration and enrichment;

e. Opportunities for worldwide communication and research.

Faktor-faktor penting lain yang perlu dipertimbangkan dalam mendesain kurikulum dan aktifitas pembelajaran untuk keperluan pembelajaran anak berbakat adalah sebagai berikut.

a. goals that support mastery of core areas of learning,

b. scope and sequence that provide meaningful organization and structure,

c. learning experiences organized around complex concepts, themes, and issues,

d. challenging, meaningful content that exceeds state grade-level standards,

e. instruction in the processes of communicating, problem solving, and critical thinking that exceeds state grade-level standards,

f. instruction in independent learning skills,

g. opportunities for worldwide communication and research,

h. products that reflect advanced achievement and in-depth research,

i. combination of acceleration and enrichment,

j. articulation with the basic core curriculum, and

k. integrated, relevant assessment of student performance.

Pertimbangan tentang karakteristik anak berbakat perlu diintegrasikan ke dalam desain program pembelajaran. Anak-anak berbakat menurut Parke (2011) pada umumnya memperlihatkan perilaku sebagai berikut. (1) menyelesaikan tugas dan pekerjaan dengan cepat; (2) kerap bertanya secara kritis untuk memperoleh pemahaman yang mendalam; (3) memilki minat yang luas yang berbeda dengan anak-anak normal seusianya. Untuk dapat merancang dan menciptakan program pembelajaran yang efektif dan efisien untuk keperluan pembelajaran anak berbakat guru dan pendidik perlu memperhatikan hal-hal berikut:

- $\quad$ kecepatan belajar anak berbakat; 
- $\quad$ kedalaman pemahaman ilmu pengetahuan;

- $\quad$ minat yang dimiliki terhadap suatu bidang.

Guru dan pendidik harus lebih banyak berperan sebagai fasilitator dalam melaksanakan program pembelajaran bagi anak berbakat. Secara spesifik guru harus berperan lebih banyak sebagai perancang, pelatih dan juga pengajar. Dalam konteks ini guru dan pendidik harus mampu membangun kemampuan belajar siswa atau anak berbakat dan memahami bagaimana proses belajar mereka. Peran seperti di atas tidak hanya menuntut guru untuk memiliki pengetahuan yang mendalam tentang isi/substansi pelajaran, tapi juga memiliki kemampuan mengajarkan isi/substansi pelajaran tersebut.

\section{KESIMPULAN DAN REKOMENDASI}

1. Buku ajar modular yang dikembangkan dalam penelitian dan pengembangan ini akan digunakan oleh guru dan pendidik sebagai bahan acuan dalam mendesain dan melaksanakan program pembelajaran bagi anak berbakat.

2. Pengembangan buku ajar modular untuk mendukung pembelajaran anak berbakat harus mempertimbangkan karakteristik anak berbakat yang antara lain meliputi; (1) gemar membaca pada usia lebih muda; (2) membaca lebih cepat dan memiliki perbendaharaan kata yang luas serta mempunyai rasa ingin tahu yang kuat; (3) mempunyai minat yang luas terhadap suatu masalah, mempunyai inisiatif, dan mampu bekerja sendiri serta menunjukkan keaslian (orisinalitas) dalam ungkapan verbal; (4) memberi jawaban-jawaban yang baik; (5) memiliki banyak gagasan; (6) luwes dalam berpikir; (7) terbuka terhadap rangsangan-rangsangan dari lingkungan. (8) mempunyai pengamatan yang tajam; (9) dapat berkonsentrasi untuk jangka waktu panjang, terutama terhadap tugas atau bidang yang diminati; (9) Berpikir kritis, juga terhadap diri sendiri; (10) senang mencoba hal-hal yang bersifat baru; (11) mempunyai daya dan kemampuan abstraksi, konseptualisasi, dan sintesis yang tinggi;

3. Pengembangan buku ajar modular perlu dilakukan secara sistematik dan sistemik yang dimulai dari langkah analisis kebutuhan, menentukan tujuan pembelajaran, menetapkan dan menyusun materi pelajaran, menentukan metode, media dan strategi pembelajaran dan mengembangkan penilaian hasil belajar.

4. Dalam melaksanakan program pembelajaran klasikal yang terdapat anak berbakat di dalamnya, guru dan pendidik harus mampu berperan sebagai pengajar dan juga fasilitator yang adil dalam memberikan perhatian kepada seluruh siswa. Siswa yang berbakat perlu diberi tantangan yang lebih besar dalam menempuh program pembelajaran agar tidak membuatnya bosan dan merasa frustasi dalam belajar.

5. Guru dan pendidik dituntut untuk berperan sebagai fasilitator dan pendamping bagi anak berbakat. Guru dan pendidik anak berbakat harus memiliki kemampuan dalam mengembangkan potensi yang dimiliki oleh anak berbakat.

\section{REFERENSI}

Dick, W. Carey, L., \& Carey, J.O. (2010). The systematic design of instruction. New Jersey: Merrill Pearson.

Gall, M.D, Gall, J.P, \& Borg, W.R. (2007). Educational research. Boston: Allyn and Bacon.

Van Tassel-Baska, J. (2013). Academically gifted and talented curriculum and instruction. Kota terbit: Penerbit.

Woolfolk, A. (2004). Educational psychology. Boston: Allyn and Bacon. 